\title{
Physiological and biochemical responses of selected cowpea (Vigna un- guiculata (L.) Walp.) accessions to iron toxicity
}

\author{
Josiah E. IFIE ${ }^{1,2,3}$, Sandra IFIE-ETUMAH ${ }^{2}$, Beckley IKHAJIAGBE ${ }^{2}$
}

Received November 26, 2018; accepted December 31, 2019. Delo je prispelo 26. novembra 2018, sprejeto 31. decembra 2019.

Physiological and biochemical responses of selected cowpea (Vigna unguiculata (L.) Walp.) accessions to iron toxicity

Abstract: This study aimed to investigate the effect of iron toxicity in cowpea using physiological and biochemical responses of selected accessions. Fifteen accessions of cowpea were exposed to two treatments of iron using $\mathrm{FeSO}_{4}$ solution ( $100 \mathrm{mg} \mathrm{l}^{-1}$ and $400 \mathrm{mg} \mathrm{l}^{-1}$ ) and distilled water at $\mathrm{pH} 6.2$ as control. The results showed that there was a general reduction in germination morphology; germination percentage among the $400 \mathrm{mg} \mathrm{l}^{-1}$ Fe-treated accessions. Seed mortality rates were significantly higher among the $400 \mathrm{mg} \mathrm{l}^{-1} \mathrm{Fe}$-treated accessions (> $35 \%$ ). Water imbibition capacity and relative mass gained were higher for Fe-treated accessions. Furthermore, significant increase in the total sugar and percentage utilization of sugars was accompanied by an insignificant decrease in chlorophyll a, a significant decrease in chlorophyll b contents and the persistence of foliar chlorosis, among the $400 \mathrm{mg} \mathrm{l}^{-1}$ Fe-treated accessions. MDA levels were significantly increased while proline remained unchanged, mean SOD activity was insignificantly increased, whereas Cat decreased among the $400 \mathrm{mg} \mathrm{l}^{-1} \mathrm{Fe}$ treated accessions. Documentation of these observable changes in physiological and biochemical parameters will be useful in understanding the impact of elevated iron concentrations on the cultivation of cowpea accessions in soils associated with ferruginous ultisols.

Key words: ferruginous ultisol; Vigna unguiculata; cowpea accessions; iron toxicity; plant antioxidants; cowpea tolerance; physiological response; biochemical response
Fiziološki in biokemični odziv akcesij kitajske vinje (Vigna unguiculata (L.) Walp.) na toksičnost železa

Izvleček: Raziskava je bila izvedena $\mathrm{z}$ namenom preučevanja učinkov toksičnosti železa na kitajsko vinjo na osnovi fiziološkega in biokemičnega odziva izbranih akcesij. 15 akcesij kitajske vinje je bilo izpostavljeno dvema obravnavanjema $\mathrm{z}$ raztopino $\mathrm{FeSO}_{4}\left(100 \mathrm{mg} \mathrm{l}^{-1}\right.$ in $\left.400 \mathrm{mg} \mathrm{l}^{-1}\right)$ in destilirano vodo pri pH 6,2 kot kontrolo. Rezultati so pokazali, da je bilo splošno zmanjšanje $\mathrm{v}$ morfoloških parametrih kalitve in $\mathrm{v}$ odstotku kalitve pri akcesijah, ki so bile tretirane s $400 \mathrm{mg} \mathrm{l}^{-1} \mathrm{Fe}$. Tudi smrtnost semen je bila pri akcesijah, tretiranih s $400 \mathrm{mg} \mathrm{l}^{-1} \mathrm{Fe}$ značilno večja (> $35 \%)$. Sposobnost nabrekanja $\mathrm{z}$ vodo in relativno povečanje mase sta bila večja pri z železom tretiranih akcesijah. Nadalje je bilo opaženo pri s $400 \mathrm{mg} \mathrm{l}^{-1} \mathrm{Fe}$ tretiranih akcesijah značilno povečanje vsebnosti celokupnih sladkorjev in njihove porabe, kar je bilo spremljano $\mathrm{z}$ neznačilnim upadom vsebnosti klorofila a, z značilnim upadom klorofila $\mathrm{b}$ in pojavom listnih kloroz. Pri obravnavanjih s $400 \mathrm{mg} \mathrm{l}^{-1} \mathrm{Fe}$ se je vsebnost MDA značilno povečala, medtem, ko so vsebnosti prolina ostale nespremenjene, poprečna aktivnost SOD se je neznačilno povečala, aktivnost Cat pa zmanjšala. Dokumentiranje teh sprememb $\mathrm{v}$ fizioloških in biokemičnih parametrih bo koristno za razumevanje vpliva povečanih koncentracij železa pri gojenju akcesij kitajske vinje $\mathrm{v}$ tleh povezanih $\mathrm{z}$ železovimi ultisoli.

Ključne besede: železov ultisol; Vigna unguiculata; akcesije kitajske vinje ; toksičnost železa; rastlinski antioksidanti; strpnost kitajske vinje; fiziološki odziv; biokemični odziv

1 Kampala International University, Western Campus, Medical Biochemistry Department, Ishaka, Uganda

2 University of Benin, Department of Plant Biology and Biotechnology, Environmental Biotechnology and Sustainability Research Group, Benin City, Nigeria

3 Corresponding author, e-mail: josiahifie@gmail.com 


\section{INTRODUCTION}

The importance of proteins in humans cannot be over-emphasized especially in its use for the development of body structures as well as regulation of human metabolism. Dietary proteins can be obtained from either the plant or animal sources according to Ahenkora et al. (1998). Many of African countries are currently struggling economically and as such it has become difficult for the citizens to purchase animal products which are major sources of proteins. Notwithstanding the economic situation especially in Nigeria, there is also the issue of health disorders associated with over-dependence on animal proteins (Spence et al., 2010) and these challenges make it imperative for the drive for cheaper and healthier alternative sources which the plant sources provide (Clinfton, 2011).

During austere times such as is prevalence in most African countries, legumes are among the safer and cheaper plant sources of proteins (Nielsen et al., 1993). Averagely, about 70 million people consume legumes globally and attempts aimed at achieving food security through these sources have prompted the need to set up farmlands and improve the technological inputs for better yields while at same time ensuring that adequate and efficient storage systems for preservation of harvested crops are in place (Diouf \& Hilu, 2005).

Though the above efforts in the achievement of nutritional sufficiency are a welcome development, environmental factors have been shown to impact significantly on crop productivity. However, human activities such as mining and other industrial activities may be a major source of heavy metal pollution to soil and these impacts negatively on crop productivity (Ikhajiagbe, 2016). The presence of heavy metal in soils usually above the limit of tolerance leads to metal toxicity and a good example is the presence of high concentrations of iron in ferruginous soils in which the available iron $\left(\mathrm{Fe}^{2+}\right)$ is greater than $300 \mathrm{mg} \mathrm{kg}^{-1}$ (Yamauchi and Peng, 1995; Ratering \& Schnell, 2000). At such high concentrations, iron becomes toxic to plants' growth and development as seen in lowland rice which has been reported in various countries including Nigeria, Colombia, Malaysia (Suresh 2005; Mitra et al., 2009).

Reports have shown that most cowpea; about $66 \%$ of global production, are grown in the African continent particularly in Nigeria and Niger. In Nigeria, most of these productions are domiciled in the Northern region (Blade et al., 1997). The conditions needed for the cultivation of cowpea such as above $80 \%$ sandy content are also present in some other states such as Edo State, Nigeria, Edo State but have recorded very low production (IITA, 2003). One of the reasons for this shortfall may be due to the presence of high iron in most of these soils (ferruginous ultisols) as shown by the geological evidence of Ikhile (2016) and collaborated by Imasuen \& Onyeobi (2013).

There is a dearth of information on the physiological and biochemical response of cowpea to elevated iron levels as most existing literature focus on rice. Therefore, the study aims to investigate iron toxicity in cowpea using physiological and biochemical responses of selected accessions which will serve as a background for the understanding of the basis of tolerance of cowpea accessions planted in a ferruginous ultisol.

\section{MATERIAL AND METHODS}

\subsection{EXPERIMENTAL DESIGN, SEED COLLECTION AND PLANTING}

Fifteen accessions (TVu-3742, TVu-3769, TVu5348, TVu-5760, TVu-5768, TVu-5782, TVu-5883, TVu6102, TVu-6193, TVu-6219, TVu-6290, TVu-10600, TVu-10881, TVu-11114, and TVu-11214) of cowpea were used in this study. The study was undertaken in the greenhouse of the Department of Plant Biology and Biotechnology, University of Benin, Nigeria. The accessions were provided by the Genetic Recourses Centre of the International Institute for Tropical Agriculture (GRC, IITA), Ibadan, Nigeria. The accessions were exposed to two treatments $\left(100 \mathrm{mg} \mathrm{l}^{-1}\right.$ and $400 \mathrm{mg} \mathrm{l}^{-1}$ ) of iron sulphate $\left(\mathrm{FeSO}_{4}\right)$ solution based on toxicity reference for soil iron $\left(300 \mathrm{mg} \mathrm{l}^{-1}\right)$ and distilled water at $\mathrm{pH} 6.2$ as control. The No. 1 Whatman's Filter papers were placed in Petri dishes moistened with the treatment solutions and thereafter ten seeds (mean mass: $0.18 \pm 0.09 \mathrm{~g}$ ) each of the fifteen accessions were planted in three replicates.

\subsection{DATA COLLECTION}

\subsubsection{Germination}

Germination parameters were assessed by methods described by Sadeghi et al. (2011). These include germination percentage, seminal root length, shoot length, leaf area of germinant, seed mortality, mean water imbibitions capacity, water imbibitions rate and relative mass gain.

\subsubsection{Total sugars and pigment analyses}

The productive capacity and pigmentation of the 
seeds and cotyledons such as total sugars, chlorophyll a and $b$ were assessed. The total sugar was estimated according to the method described by Nelson (1944) and modified by Sankar \& Selvaraju (2015). Chlorophyll a and $\mathrm{b}$ contents were investigated according to methods described by Arnon et al (1949) and Maxwell \& Johnson (2000).

\subsubsection{Characterization of iron toxicity symptoms}

For characterization of FE-induced chlorosis, morphological observations of the plant in response to the experimental conditions were recorded on an intermittent basis. These observations include the colour, shape, form or the appearance of the leaves and the stem of the plant as well as the positioning of flowers and nodes. Care was also taken to make sure that the succession of chlorosis was recorded.

\subsubsection{Antioxidant activities}

Enzymatic (catalase, superoxide dismutase) and non-enzymatic (proline and malondialdehyde) antioxidants parameters were evaluated in the seeds and cotyledons of successfully germinated accessions. SOD activity was determined by the methods of Beauchamp \& Fridovich (1971) and described by Ranganayakulu et al. (2013). Catalase activity was measured by the method of Luck (1971) and modified by Esma \& Gulnur, (2016). MDA was determined using the thiobarbituric acid assay method described by Health \& Packer (1968) and modified by Erja et al (2001). The extraction and estimation of proline were done according to the methods of Bates et al (1973) and Marin et al (2006).

\subsection{STATISTICAL ANALYSIS.}

Data obtained from this study were subjected to a two-way analysis of variance using the SPSS statistical analysis software (SPSS-20). Students' T-test and the least significant difference; LSD was used for equality of means while the Levene's test was used for the analysis of equality of variances. All statistical analysis was performed at a confidence limit of $95 \%(p=0.05)$ and values are presented as mean \pm standard deviation.

\section{RESULTS AND DISCUSSION}

\subsection{RESULTS}

The results obtained from this study showed the germination (\%) of TVu-3769, 5760 and 6219 were significantly higher for control as well as the mean germ (\%) when compared to the $100 \mathrm{mg} \mathrm{l}^{-1}$ and the $400 \mathrm{mg} \mathrm{l}^{-1}$ Fe-treated accessions (Fig 1). The seminal root length of TVu-5348, 6219, 11114 and mean value of control accessions were significantly higher compared to the $100 \mathrm{mg} \mathrm{l}^{-1}$ and the $400 \mathrm{mg} \mathrm{l}^{-1} \mathrm{Fe}$-treated accessions (Fig 2). For shoot length, TVu-3769 and 11214 showed significantly higher values for control accessions whereas TVu-5348, 5760, 5782, 6290 and 10600 were significantly higher for $100 \mathrm{mg} \mathrm{l}^{-1} \mathrm{Fe}$-treated accessions. Comparison of the mean values of control, $100 \mathrm{mg} \mathrm{l}^{-1}$ and the $400 \mathrm{mg} \mathrm{l}^{-1}$, showed a significantly higher mean for $100 \mathrm{mg} \mathrm{l}^{-1}$ Fe-treated accessions (Fig 3).

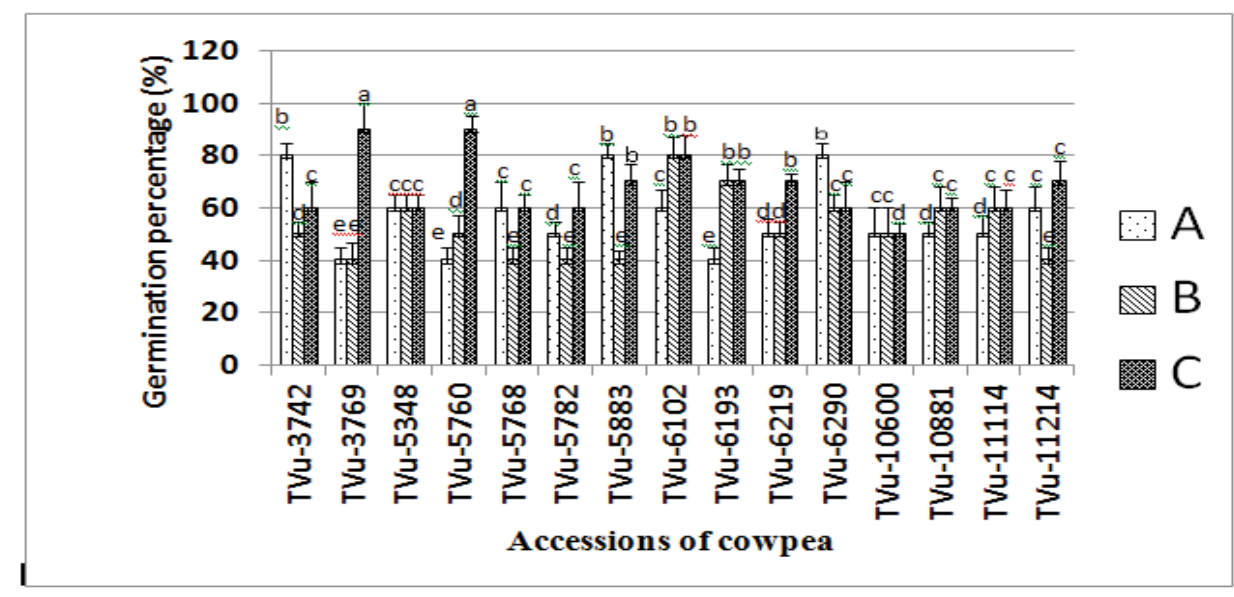

Figure 1: Final germination percentage of accessions after 1 week following germination initiation. A: Seeds treated with $100 \mathrm{mg} \mathrm{l}^{-1} \mathrm{FeSO}_{4}$ Soln., B: Seeds treated with $400 \mathrm{mg} \mathrm{l}^{-1} \mathrm{FeSO}_{4}$ Soln. and C: Control. ${ }^{*}$ Mean values of accessions with different letters show statistical significance. 
The leaf area of $\mathrm{TVu}-5348,5883,6193$ and 10600 was significantly higher in control accessions. Also, the mean value of control accessions was higher when compared to $100 \mathrm{mg} \mathrm{l}^{-1}$ and $400 \mathrm{mg} \mathrm{l}^{-1} \mathrm{Fe}$-treated accessions, the mean differences were statistically insignificant (Fig 4). The mean seed mortality (\%) showed a significantly higher value for $400 \mathrm{mg} \mathrm{l}^{-1}$ accessions compared to the control and insignificant when compared to $100 \mathrm{mg} \mathrm{l}^{-1}$ Fe-treated accessions. The least mean value was observed in the control accessions (Fig 5).

The water imbibition capacity, water imbibition rate and relative mass gain of $\mathrm{TVu}-10881$ were significantly higher in control (Fig 6, 7 and 8) but, comparison of the mean values of the control, $100 \mathrm{mg} \mathrm{l}^{-1}$ and $400 \mathrm{mg} \mathrm{l}^{-1} \mathrm{Fe}-$ treated accessions show no significance (Fig 6). Tvu-3769 showed a significantly higher value for water imbibition rate and relative mass gain for the $100 \mathrm{mg} \mathrm{l}^{-1}$ and 400 $\mathrm{mg} \mathrm{l}^{-1} \mathrm{Fe}$-treated accessions while the comparison of the mean values was statistically insignificant (Fig 7 and 8).

For the plants' productive capacity, the total sugar of germinated seeds was compared to the seeds obtained for studies from the IITA. The results showed that the seeds from IITA had significantly higher total sugar (Fig 9). However, the mean total sugar of $100 \mathrm{mg} \mathrm{l}^{-1}$ was higher than $400 \mathrm{mg} \mathrm{l}^{-1} \mathrm{Fe}$-treated and control accessions. These mean differences among $100 \mathrm{mg} \mathrm{l}^{-1}$, $400 \mathrm{mg} \mathrm{l}^{-1} \mathrm{Fe}$-treated and control accessions were insignificant $(p>0.05)$. Accessing the total sugar contents of the cotyledons showed a significantly higher value for $\mathrm{TVu}-6219$ in control accessions meanwhile comparison the mean values among

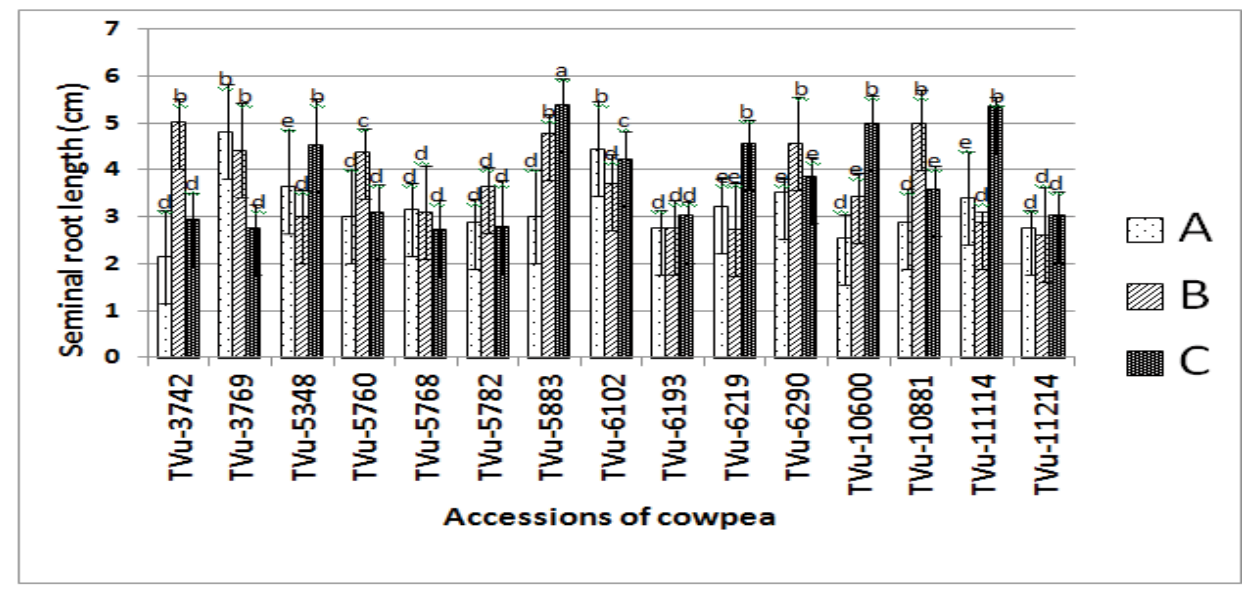

Figure 2: Seminal root length of accessions after 5 days following germination initiation. A: Seeds treated with $100 \mathrm{mg} \mathrm{l}^{-1} \mathrm{FeSO}_{4}$ Soln., B: Seeds treated with $400 \mathrm{mg} \mathrm{l}^{-1} \mathrm{FeSO}_{4}$ Soln. and C: Control. *Mean values of accessions with different letters show statistical significance.

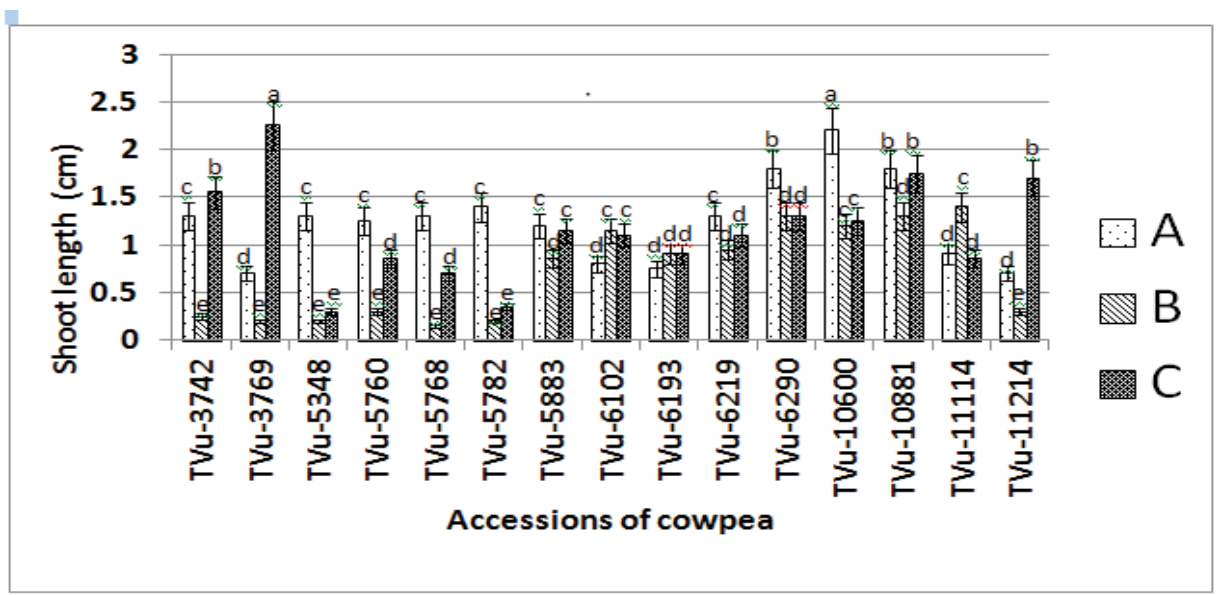

Figure 3: Shoot length of accessions after 5 days following germination initiation. A: Seeds treated with $100 \mathrm{mg} \mathrm{l}^{-1} \mathrm{FeSO}_{4}$ Soln., B: Seeds treated with $400 \mathrm{mg} \mathrm{l}^{-1} \mathrm{FeSO}_{4}$ Soln. and C: Control. *Mean values of accessions with different letters show statistical significance. 


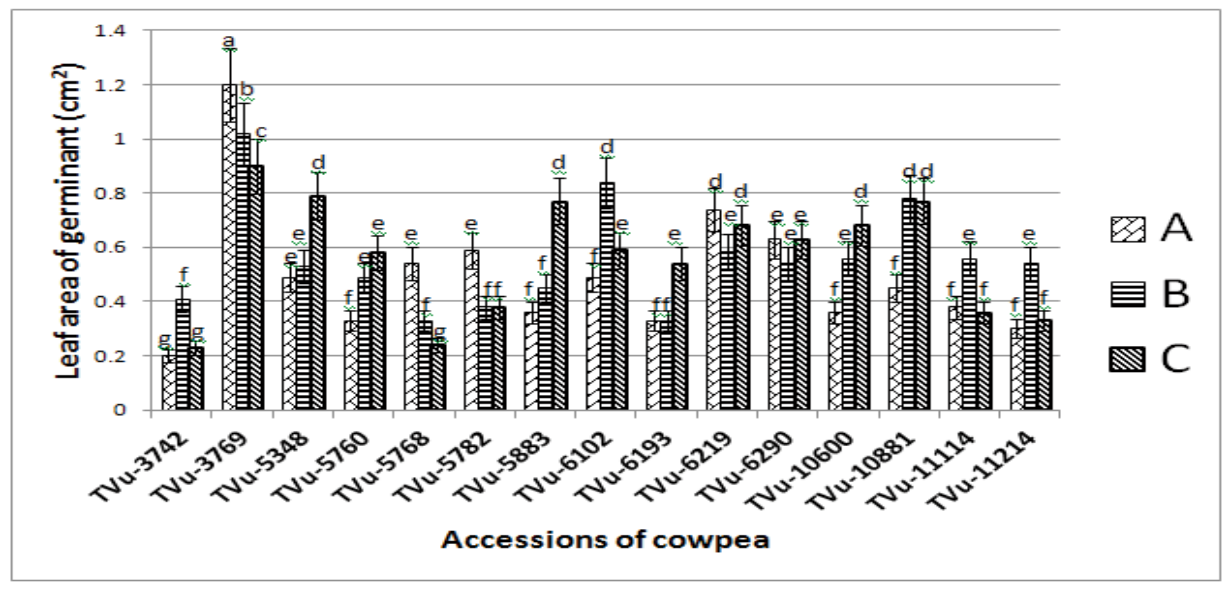

Figure 4: Leaf area of early developing accessions after 1 week following germination initiation. A: Seeds treated with $100 \mathrm{mg} \mathrm{l}^{-1} \mathrm{FeSO}_{4}$ Soln., B: Seeds treated with $400 \mathrm{mg} \mathrm{l}^{-1} \mathrm{FeSO}_{4}$ Soln. and C: Control. ${ }^{*}$ Mean values of accessions with different letters show statistical significance..

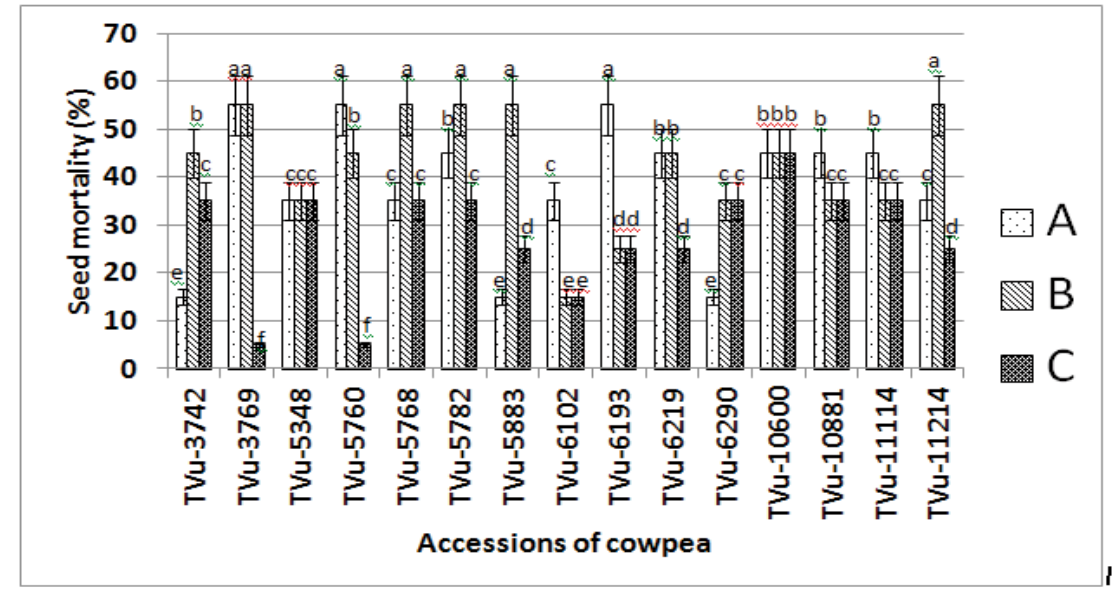

Figure 5: Percentage seed mortality at 21 days after germination initiation.

A: Seeds treated with $100 \mathrm{mg} \mathrm{l}^{-1} \mathrm{FeSO}_{4}$ Soln., B: Seeds treated with $400 \mathrm{mg} \mathrm{l}^{-1} \mathrm{FeSO}_{4}$ Soln. and C: Control. "Mean values of accessions with different letters show statistical significance.

$100 \mathrm{mg} \mathrm{l}^{-1}, 400 \mathrm{mg} \mathrm{l}^{-1} \mathrm{Fe}$-treated and control accessions were insignificant $(p>0.05)$ as seen in Figure 10. The percentage utilization of sugar showed a significantly higher mean value for $400 \mathrm{mg} \mathrm{l}^{-1}$ compared to $100 \mathrm{mg} \mathrm{l}^{-1}$ Fe-treated and control accessions $(p<0.05)$ as seen in Table 1.0.

Table 2.0 showed the Chlorophyll-a (Chl a) and b (Chl b) contents of cotyledon after 1 week following germination initiation. For $\mathrm{Chl}$ a, the highest value was seen in Tvu-10881 (0.139 $\left.\mathrm{mg} \mathrm{g}^{-1}\right)$ among $100 \mathrm{mg} \mathrm{l}^{-1}$ Fe-treated accessions and the least in Tvu-10600 (0.032 $\left.\mathrm{mg} \mathrm{g}^{-1}\right)$ among control accessions. Statistically, insignificant differential mean values were observed when the control accessions were compared with the Fe-treated accessions. For $\mathrm{Chl} \mathrm{b}$, the highest value was observed in Tvu-10881
(0.251 $\left.\mathrm{mg} \mathrm{g}^{-1}\right)$ among $100 \mathrm{mg} \mathrm{l}^{-1}$ Fe-treated accessions and the least in Tvu-10600 (0.057 $\left.\mathrm{mg} \mathrm{g}^{-1}\right)$ among control. The mean chlorophyll $b$ value of $100 \mathrm{mg} \mathrm{l}^{-1}$ Fe-treated accessions was higher while the $400 \mathrm{mg} \mathrm{l}^{-1} \mathrm{Fe}$-treated was lower compared to the control. These mean differences were statistically significant. The mean total chlorophyll value for the $100 \mathrm{mg} \mathrm{l}^{-1} \mathrm{Fe}$-treated accessions was higher while the $400 \mathrm{mg} \mathrm{l}^{-1} \mathrm{Fe}$-treated was lower when compared to the control. However, these mean differences are statistically insignificant. The ratio of $\mathrm{Chl}$ a to $\mathrm{Chl} \mathrm{b}$ showed insignificant equal mean values among the $100 \mathrm{mg} \mathrm{l}^{-1}$, $400 \mathrm{mg} \mathrm{l}^{-1}$ and the control accessions. Table 3.0 shows the persistence of chlorosis on germinants at 5, 6 and 7 days after germination with the mean persistence of chlorosis being more evident $(++$ and +++$)$ among the Fe-treated 


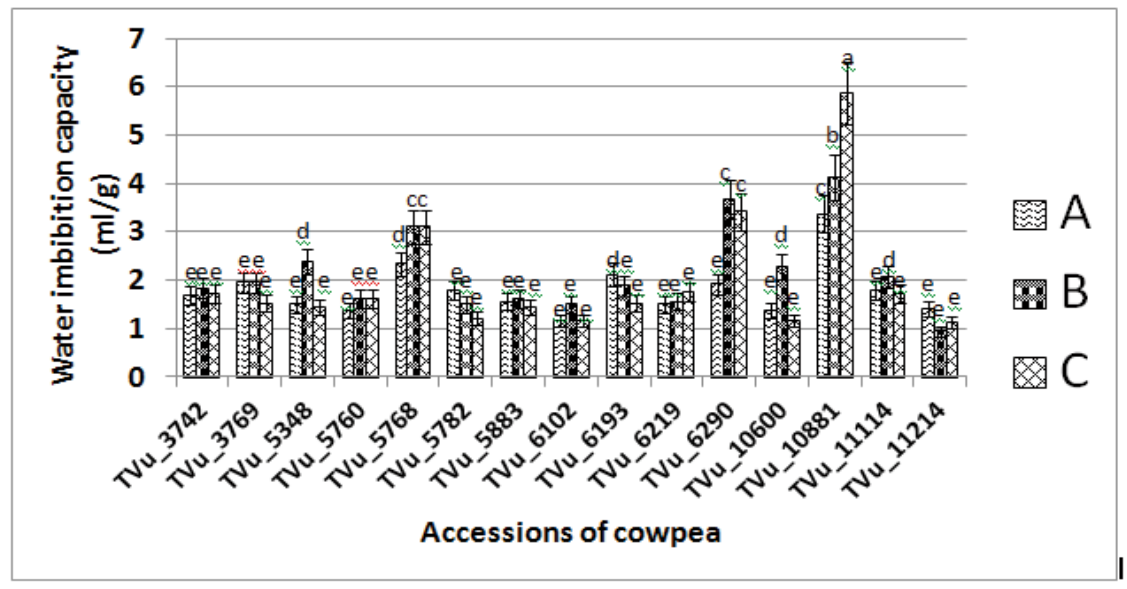

Figure 6: Water imbibition capacity at 4 days after germination initiation.

A: Seeds treated with $100 \mathrm{mg} \mathrm{l}^{-1} \mathrm{FeSO}_{4}$ Soln., B: Seeds treated with $400 \mathrm{mg} \mathrm{l}^{-1} \mathrm{FeSO}_{4}$ Soln. and C: Control. ${ }^{*}$ Mean values of accessions with different letters show statistical significance.

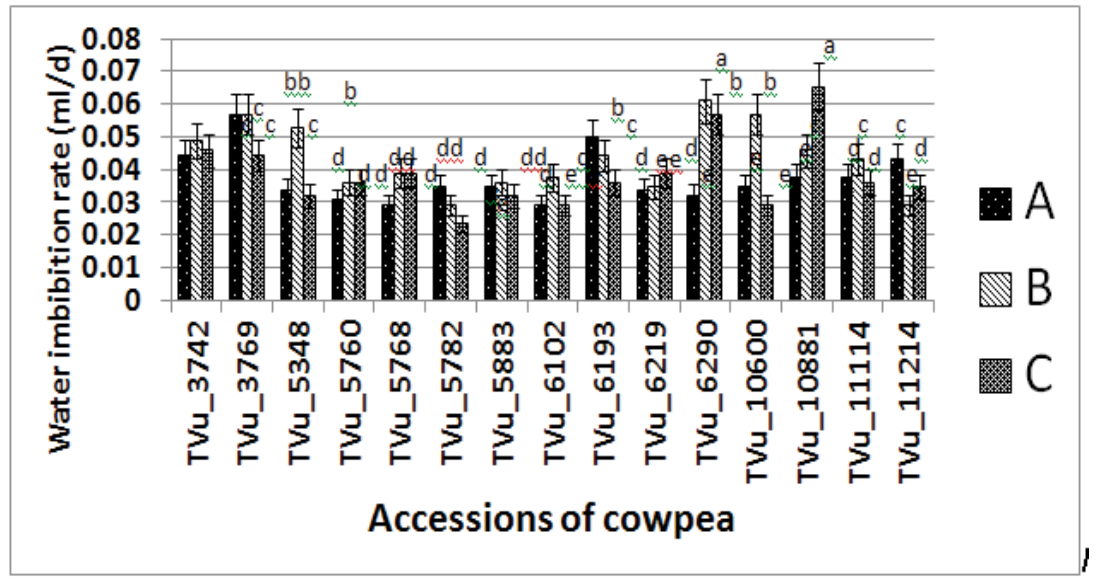

Figure 7: Water imbibition rate 4 days after germination initiation A: Seeds treated with $100 \mathrm{mg} \mathrm{l}^{-1} \mathrm{FeSO}_{4}$ Soln., B: Seeds treated with $400 \mathrm{mg} \mathrm{l}^{-1} \mathrm{FeSO}_{4}$ Soln. and C: Control. ${ }^{*}$ Mean values of accessions with different letters show statistical significance

accessions (100 $\mathrm{mg} \mathrm{l}^{-1}$ and $400 \mathrm{mg} \mathrm{l}^{-1}$ ) at early days of germination compared to the controlled accessions (+).

Antioxidant capacities of the accessions showed that the MDA levels of TVu-3769, 6193, 10881 and 11114 were significantly higher among the control group (Fig 11). Comparison of the mean MDA values of $100 \mathrm{mg} \mathrm{l}^{-1}$, $400 \mathrm{mg} \mathrm{l}^{-1}$ and control showed that the mean value of control was significantly higher but those of proline were statistically insignificant (Fig 12). Catalase activities of TVu-6193 and 11214 were significantly higher in the control group compared to Fe-treated accessions (Fig 13). Comparison of the mean CAT activities among $100 \mathrm{mg} \mathrm{l}^{-1}, 400 \mathrm{mg} \mathrm{l}^{-1}$ and control accessions showed a significant least value for $400 \mathrm{mg} \mathrm{l}^{-1} \mathrm{Fe}$-treated accessions while a significantly higher mean value for the $400 \mathrm{mg} \mathrm{l}^{-1}$
Fe-treated accessions was observed for SOD activities when compared to the $100 \mathrm{mg} \mathrm{l}^{-1}$ and control accessions (Fig 14).

\subsection{DISCUSSIONS}

The findings of this study showed that iron toxicity significantly reduced germination parameters as evident in the lower germination (\%), seminal root and shoot lengths and leaf area of germinants whereas seed mortality is significantly increased. Also, the productive capacities of the accessions were significantly reduced among $400 \mathrm{mg} \mathrm{l}^{-1} \mathrm{Fe}$-treated accessions while insignificant mean differences were observed for chlorophyll a. However, Fe- 


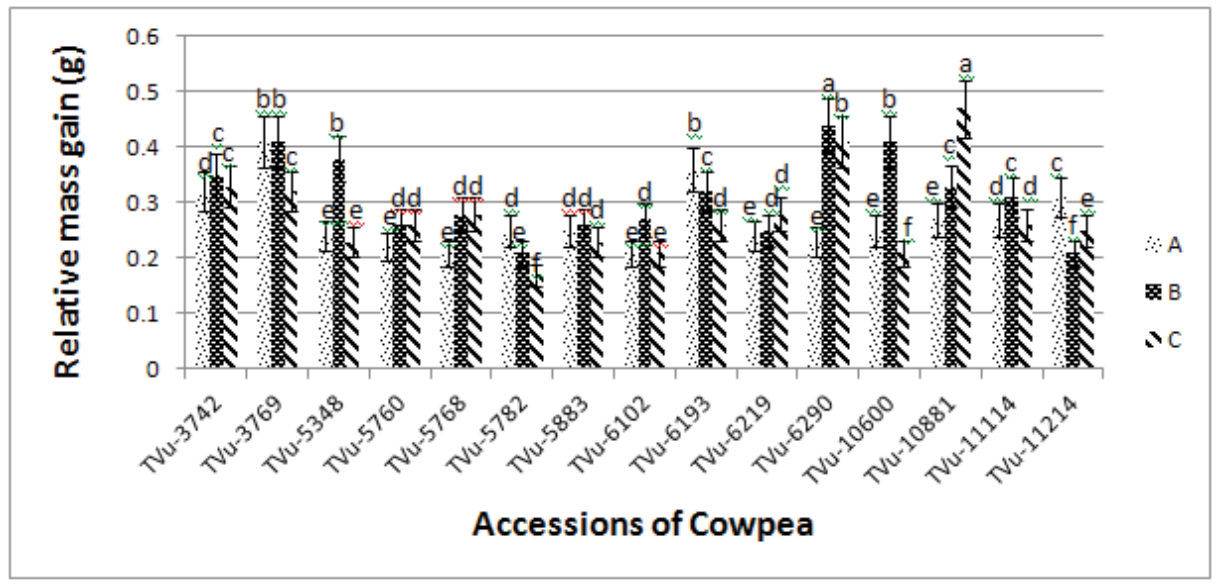

Figure 8: Relative seed mass of imbibed seeds 4 days after germination initiation. A: Seeds treated with $100 \mathrm{mg} \mathrm{l}^{-1} \mathrm{FeSO}_{4}$ Soln., B: Seeds treated with $400 \mathrm{mg} \mathrm{l}^{-1} \mathrm{FeSO}_{4}$ Soln. and C: Control. ${ }^{*}$ Mean values of accessions with different letters show statistical significance.

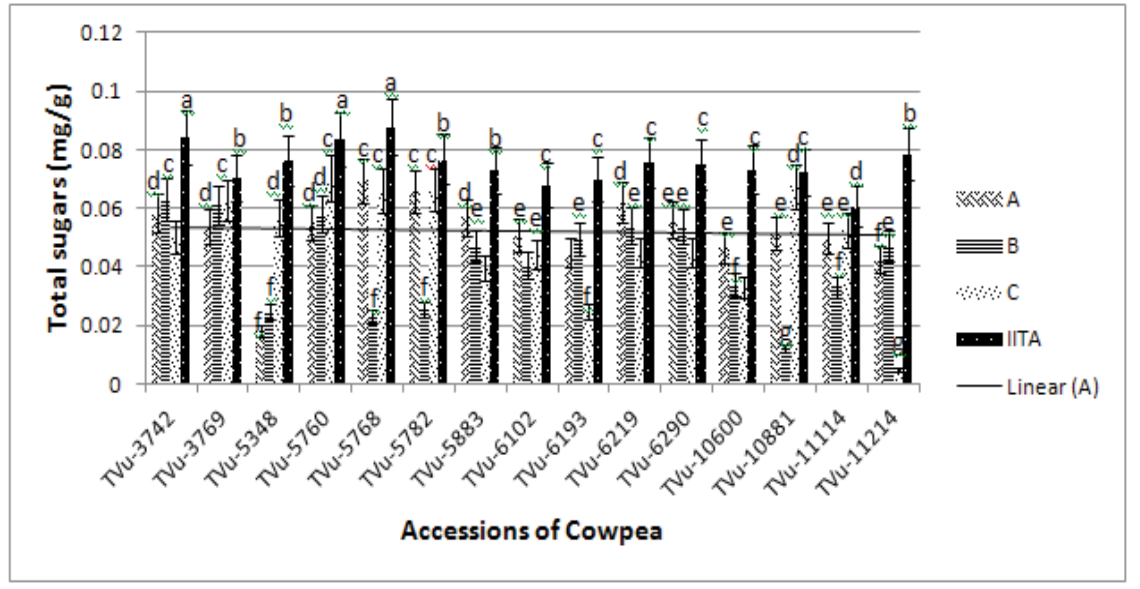

Figure 9: Total sugars of germinated seeds at 4 days following germination initiation. A: Seeds treated with $100 \mathrm{mgl}^{-1} \mathrm{FeSO}_{4}$ Soln., B: Seeds treated with 400 $\mathrm{mg} \mathrm{l}^{-1} \mathrm{FeSO}_{4}$ Soln. and C: Control. *Mean values of accessions with different letters show statistical significance.

toxicity significantly reduced the chlorophyll $\mathrm{b}$ content as well as increased persistence of chlorosis among the $400 \mathrm{mg} \mathrm{l}^{-1} \mathrm{Fe}$-treated accessions. The plants' antioxidants defence capacity showed significant lower catalase and higher SOD activities among the $400 \mathrm{mg} \mathrm{l}^{-1}$ Fe-treated accessions which corresponded with significant higher MDA values while the proline content is unchanged.

Plant germination is usually affected by the difference in genetic make-ups of the different plants as well as environmental factors such as the presence of heavy metals (Bhagyashree et al., 2016). Seed germination is a significant stage in the seedling establishment; it decides successful crop and yield production (Bhattacharjee, 2008). The reduced values for germination parameters obtained from this study is consistent with the results of
Ahmad et al. (2012) and Abdel-Haleem (2015). Though arguably, the reduced germination parameters may not be due to iron overload but rather due to general nutrient deficiencies, the presence of iron oxide deposits on the roots of wetland plants could act as a filter for nutrients such as phosphate, thereby causing a deficiency in the aerial parts of the plant. Furthermore, the physicchemical effects of iron on osmotic balance through the increase of osmotic pressure with the tendency to disrupt seed hydration may be a contributory factor for the reduced seed germination (Nabil \& Coudret, 1995; Onyango et al., 2019).

The significance of water in seed germination is critical; thus the capacity for water imbibition by plant seeds is necessary for successful germination initiation 


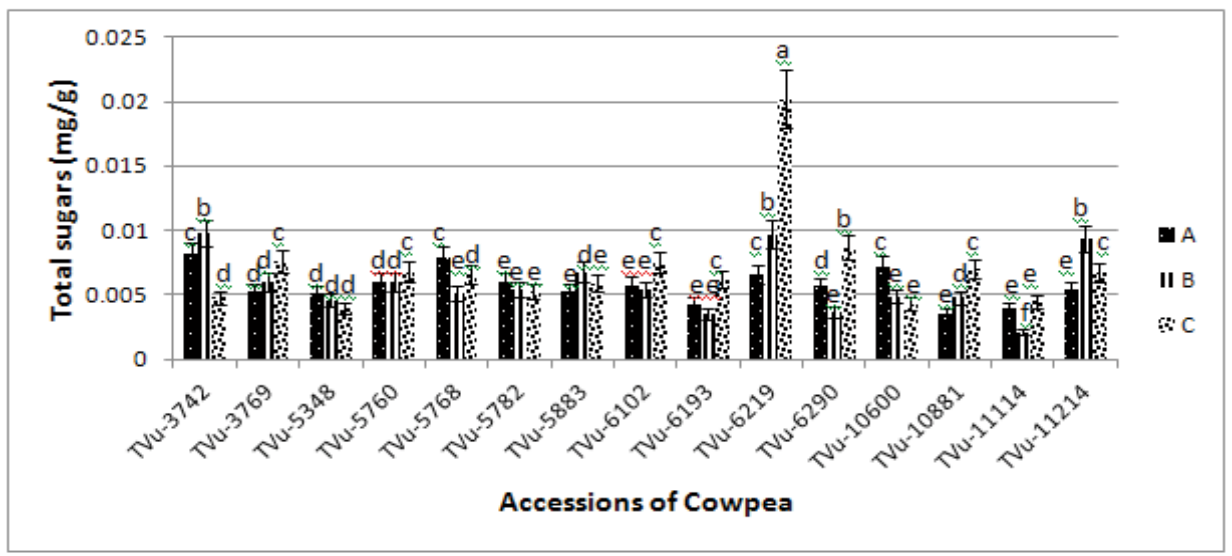

Figure 10: Total sugars of cotyledons at 4 days following germination initiation.

A: Seeds treated with $100 \mathrm{mg} \mathrm{l}^{-1} \mathrm{FeSO}_{4}$ Soln., B: Seeds treated with $400 \mathrm{mg} \mathrm{l}^{-1} \mathrm{FeSO}_{4}$ Soln. and C: Control.

${ }^{*}$ Mean values of accessions with different letters show statistical significance.

Table 1: Percentage utilization of sugars during germination (taken at 4 days after germination initiation)

\begin{tabular}{|c|c|c|c|c|}
\hline \multirow[t]{2}{*}{ Accessions } & \multicolumn{4}{|c|}{ Utilisation (\%) } \\
\hline & Group A & Group B & Group C & p-value \\
\hline TVu-3742 & $30.76^{\mathrm{f}}$ & $25.06^{\mathrm{g}}$ & $40.26^{\mathrm{e}}$ & 0.192 \\
\hline TVu-3769 & $23.83^{\mathrm{h}}$ & $13.33^{\mathrm{h}}$ & $11.06^{\mathrm{h}}$ & 0.114 \\
\hline TVu-5348 & $76.47^{b}$ & $67.71^{\mathrm{c}}$ & $25.88^{\mathrm{g}}$ & 0.011 \\
\hline TVu-5760 & $34.01^{\mathrm{f}}$ & $30.54^{\mathrm{f}}$ & $15.57^{f}$ & 0.089 \\
\hline TVu-5768 & $20.75^{\mathrm{g}}$ & $73.66^{\mathrm{b}}$ & $24.74^{\mathrm{g}}$ & 0.012 \\
\hline TVu-5782 & $14.21^{\mathrm{h}}$ & $66.88^{c}$ & $13.69^{h}$ & 0.033 \\
\hline TVu-5883 & $21.81^{\mathrm{g}}$ & $35.53^{e}$ & $45.40^{\mathrm{e}}$ & 0.051 \\
\hline TVu-6102 & $25.26^{\mathrm{g}}$ & $40.23^{e}$ & $35.39^{\mathrm{e}}$ & 0.216 \\
\hline TVu-6193 & $35.62^{f}$ & $29.33^{\mathrm{g}, \mathrm{f}}$ & $64.81^{\mathrm{c}}$ & 0.037 \\
\hline TVu-6219 & $17.72^{\mathrm{h}}$ & $28.31^{\mathrm{g}, \mathrm{f}}$ & $40.61^{\mathrm{e}}$ & 0.033 \\
\hline TVu-6290 & $25.37^{\mathrm{g}}$ & $28.44^{\mathrm{g} . \mathrm{f}}$ & $40.19^{e}$ & 0.052 \\
\hline TVu-10600 & $36.20^{f}$ & $53.55^{\mathrm{d}}$ & $55.05^{\mathrm{d}}$ & 0.051 \\
\hline TVu-10881 & $28.63^{\mathrm{g}}$ & $82.85^{\mathrm{a}}$ & $6.50^{\mathrm{i}}$ & 0.001 \\
\hline TVu-11114 & $18.09^{\mathrm{h}}$ & $45.39^{e}$ & $13.32^{\mathrm{h}}$ & 0.050 \\
\hline TVu-11214 & $30.76^{\mathrm{g}}$ & $25.06^{\mathrm{g}}$ & $40.26^{\mathrm{e}}$ & 0.060 \\
\hline $\mathrm{p}$-value & 0.023 & 0.032 & 0.026 & \\
\hline
\end{tabular}

A: Seeds treated with $100 \mathrm{mg} \mathrm{l}^{-1} \mathrm{FeSO}_{4}$ Soln., B: Seeds treated with 400 $\mathrm{mg} \mathrm{l}^{-1} \mathrm{FeSO}_{4}$ Soln. and C: Control. "Mean values of accessions with different letters show statistical significance.

and this has been shown to be affected by the difference in the permeability of the seed testa, seed composition and the availability of water in the environment (Wada and Abubbakar, 2013). Water imbibition capacity responses differed across the accessions. The low osmotic potential has been shown to extend the time needed for imbibition as well as delaying the onset of germination. Results obtained were similar to those of Olasoji et al. (2013) and Araujo et al. (2016) who also observed differential response for the rate of water of imbibition for 


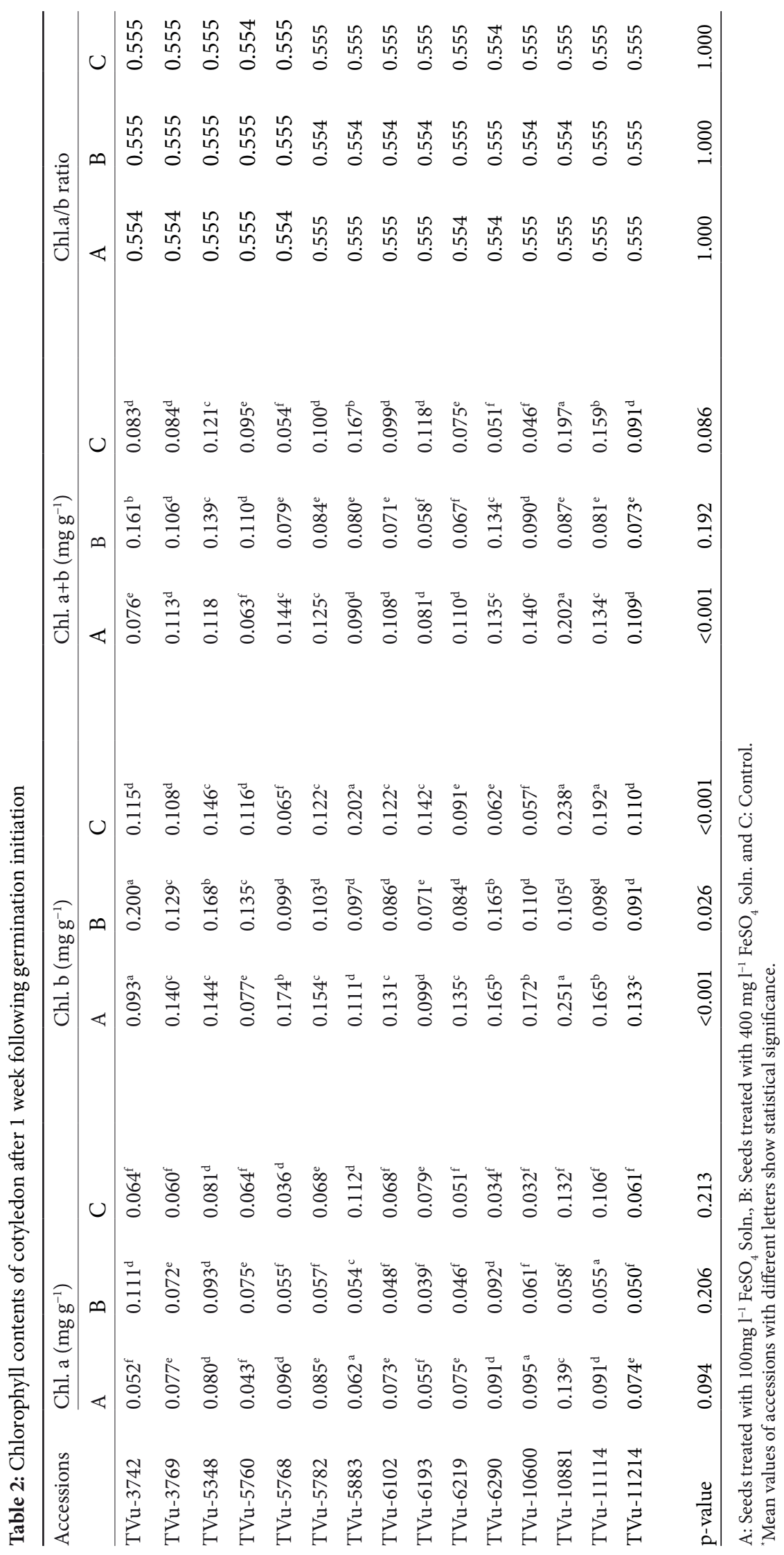


Table 3: Percentage utilization of sugars during germination (taken at 4 days after germination initiation)

\begin{tabular}{|c|c|c|c|c|c|c|c|c|c|}
\hline \multirow[t]{3}{*}{ Accessions } & \multicolumn{3}{|c|}{ Group A } & \multicolumn{3}{|c|}{ Group B } & \multicolumn{3}{|c|}{ Group C } \\
\hline & \multicolumn{9}{|c|}{ Days } \\
\hline & 5 & 6 & 7 & 5 & 6 & 7 & 5 & 6 & 7 \\
\hline TVu-3742 & +++ & + & ++ & ++ & ++ & ++ & ++ & + & + \\
\hline TVu-3769 & ++ & ++ & ++ & +++ & ++ & ++ & ++ & ++ & + \\
\hline TVu-5348 & ++ & + & + & + & - & + & ++ & + & + \\
\hline TVu-5760 & ++ & +++ & ++ & + & ++ & ++ & ++ & + & + \\
\hline TVu-5768 & ++ & ++ & ++ & ++ & ++ & + & ++ & ++ & + \\
\hline TVu-5782 & +++ & +++ & ++ & +++ & +++ & ++ & ++ & ++ & + \\
\hline TVu-5883 & +++ & + & + & +++ & + & + & +++ & + & + \\
\hline TVu-6102 & ++ & ++ & + & +++ & ++ & ++ & ++ & ++ & ++ \\
\hline TVu-6193 & +++ & ++ & + & ++ & +++ & + & ++ & + & + \\
\hline TVu-6219 & +++ & ++ & + & +++ & ++ & ++ & ++ & + & - \\
\hline TVu-6290 & +++ & +++ & + & +++ & ++ & + & +++ & ++ & + \\
\hline TVu-10600 & ++ & + & ++ & +++ & + & ++ & ++ & + & ++ \\
\hline TVu-10881 & ++ & +++ & ++ & ++ & ++ & ++ & + & + & + \\
\hline TVu-11114 & +++ & +++ & ++ & ++ & + & ++ & ++ & + & + \\
\hline TVu-11214 & ++ & +++ & ++ & +++ & ++ & ++ & ++ & + & ++ \\
\hline
\end{tabular}

A: Seeds treated with $100 \mathrm{mg} \mathrm{l}^{-1} \mathrm{FeSO}_{4}$ Soln., B: Seeds treated with $400 \mathrm{mg} \mathrm{l}^{-1} \mathrm{FeSO}_{4}$ Soln. and C: Control. "Mean values of accessions with different letters show statistical significance.

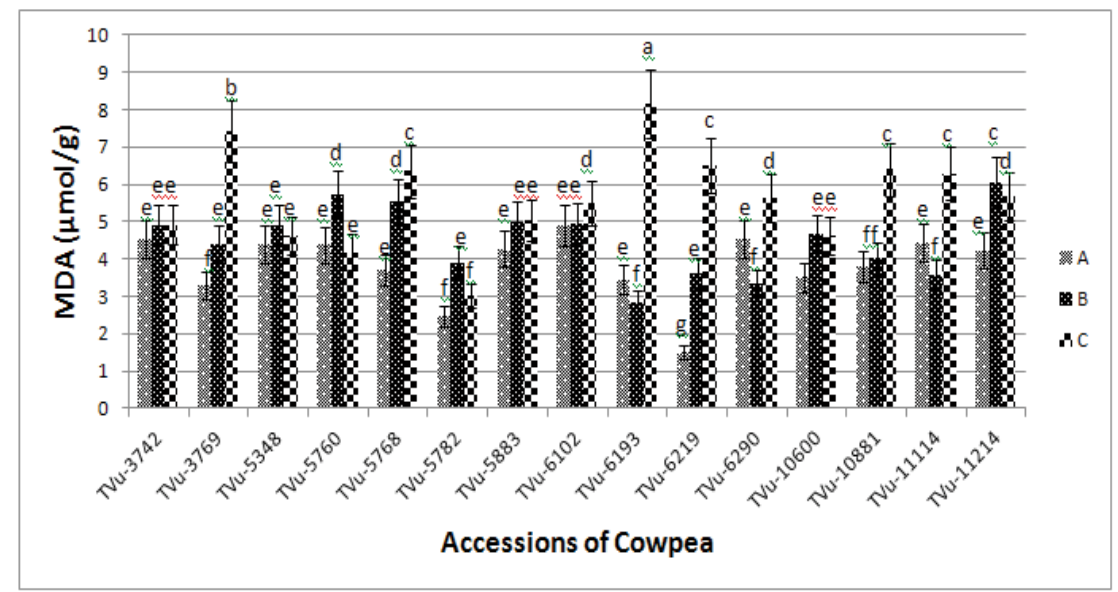

Figure 11: MDA activity of cotyledons of accessions after 1 week following germination initiation.

A: Seeds treated with $100 \mathrm{mg} \mathrm{l}^{-1} \mathrm{FeSO}_{4}$ Soln., B: Seeds treated with $400 \mathrm{mg} \mathrm{l}^{-1} \mathrm{FeSO}_{4}$ Soln. and C: Control.

${ }^{*}$ Mean values of accessions with different letters show statistical significance.

plants exposed to heavy metal toxicity and Dufey et al. (2009) who observed decreased relative water content of rice exposed to iron toxicity.

Plant productivity can be assessed using total sugars and percentage utilization of sugar during germination. It can also be important in the determination of the extent of iron toxicity. The increased utilization of sugars in the germinating seeds, as well as the cotyledons with exposure to $\mathrm{Fe}$, may not be unconnected to the increased use of sugar for productivity especially in combating stress posed by the iron toxicity. These findings are inconsistent with those of Priti et al. (2009) and Ezhilvannan et al. (2011) but consistent with the findings of Onyango 


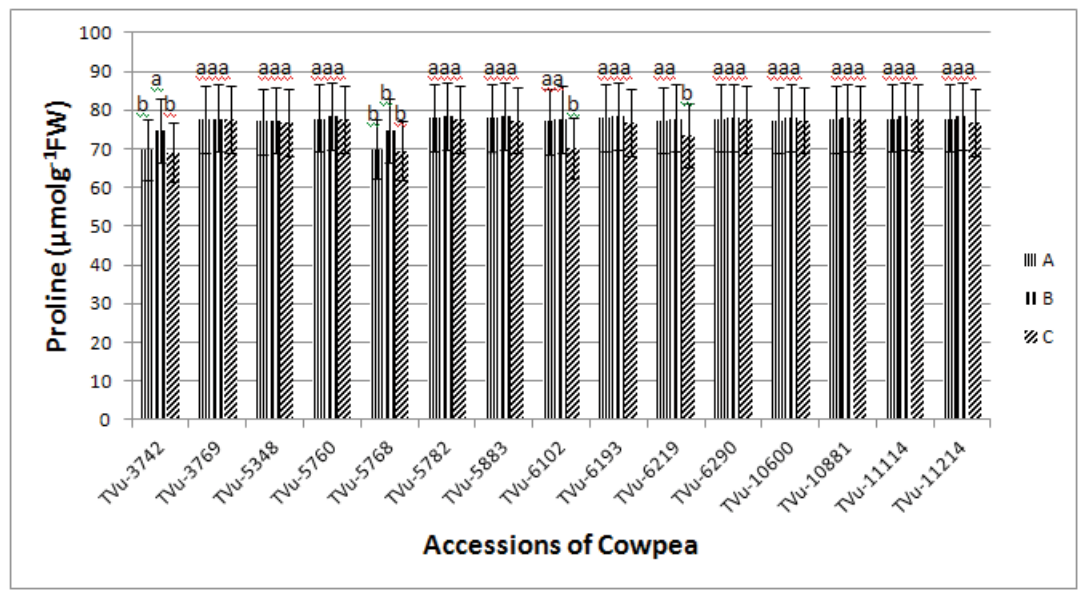

Figure 12: Proline levels in germinants at 7 days after germination initiation. A: Seeds treated with $100 \mathrm{mg} \mathrm{l^{-1 }} \mathrm{FeSO}_{4} \mathrm{Soln}_{\text {., }} \mathrm{B}$ : Seeds treated with $400 \mathrm{mg} \mathrm{l}^{-1} \mathrm{FeSO}_{4}$ Soln. and C: Control. ${ }^{*}$ Mean values of accessions with different letters show statistical significance.

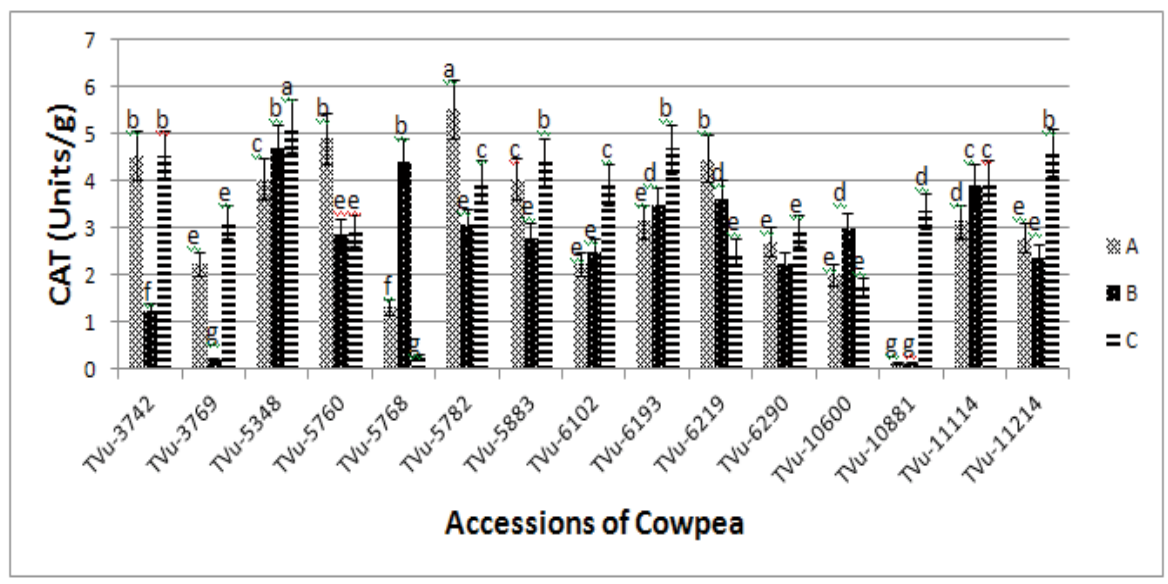

Figure 13: CAT activity of cotyledons of accessions after 1 week following germination initiation.A: Seeds treated with $100 \mathrm{mg} \mathrm{l}^{-1}$ $\mathrm{FeSO}_{4}$ Soln., B: Seeds treated with $400 \mathrm{mg} \mathrm{l}^{-1} \mathrm{FeSO}_{4}$ Soln. and C: Control. ${ }^{*}$ Mean values of accessions with different letters show statistical significance.

et al. (2019) who observed a reduction in soluble sugar content in rice exposed to iron toxicity.

Development of oxidative stress in plants exposed to heavy metals is largely ascribed to the heavy metalinduced imbalance between the generations of toxic oxygen radicals and their scavenging through the antioxidative defence mechanisms. With increasing concentrations of heavy metals, it is expected to observe an increased lipid peroxidation and increased activities of anti-oxidative enzymes such as SOD, GSH and catalase (Priti et al., 2009; Arleta et al., 2012). Activities of SOD and catalase were observed to be concentration-dependent and have an initial increase as concentration increase but a reduced value was later observed upon exposure to Pb-toxicity (Malar et al., 2016). Superoxide dismutase is considered as a first-line defence system against ROS, as it acts on superoxide free radicals, which are produced in different compartments of the cell and are precursors of the other ROS (Priti et al., 2009). It is involved in the dismutation of the oxygen-free radical; $\mathrm{O}_{2}^{-}$into $\mathrm{H}_{2} \mathrm{O}_{2}$ (Sun et al., 2009). Hence, it is expected for its increase during plant stress in response to heavy metal accumulation such as increase Fe concentration. These results are in consistence with the findings of Prasad et al. (2014) but inconsistence with the findings of Sadeghipour et al. (2008) in which reduced catalase activities were recorded.

The $\mathrm{H}_{2} \mathrm{O}_{2}$ produced from the dismutation of $\mathrm{O}_{2}^{-}$is expected to be cleared by peroxidase via the reduction of hydrogen peroxide $\left(\mathrm{H}_{2} \mathrm{O}_{2}\right)$ into water $\left(\mathrm{H}_{2} \mathrm{O}\right)$ and oxygen 


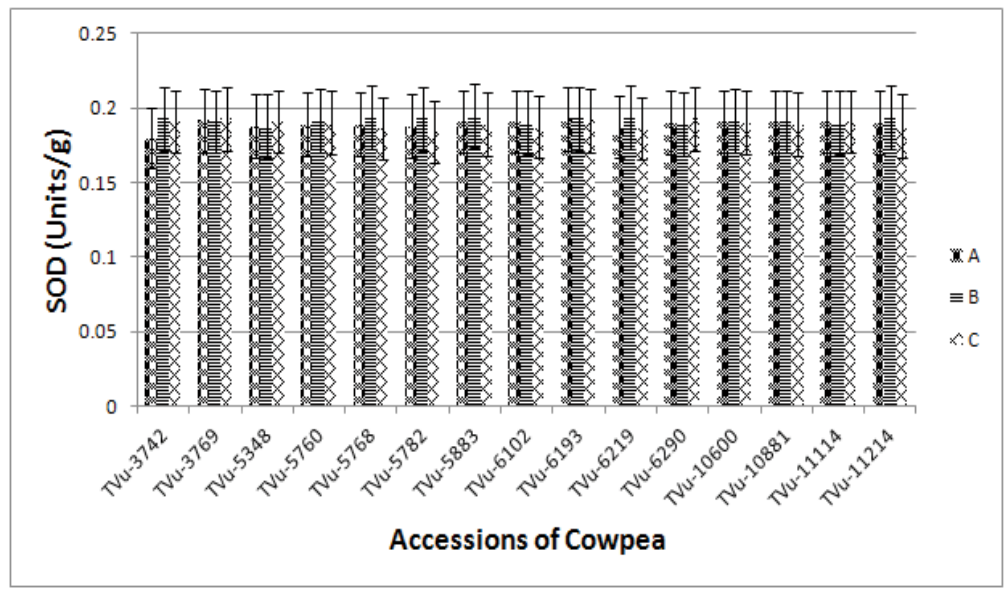

Figure 14: SOD activity of cotyledons of accessions after 1 week following germination initiation.A: Seeds treated with $100 \mathrm{mg} \mathrm{l}^{-1}$ $\mathrm{FeSO}_{4}$ Soln., B: Seeds treated with $400 \mathrm{mg} \mathrm{l}^{-1} \mathrm{FeSO}_{4}$ Soln. and C: Control. Mean values of accessions show no statistical significance.

$\left(\mathrm{O}_{2}\right)$. At overwhelming levels of $\mathrm{H}_{2} \mathrm{O}_{2}$, catalase is mobilized for a further breakdown of the $\mathrm{H}_{2} \mathrm{O}_{2}$ (Gao et al., 2010). Therefore it can be suggestive that the insignificant change in catalase activity may be as a result of the ability of peroxidase to scavenge the hydrogen peroxide produced by SOD. MDA was reduced under Fe exposure which is perhaps an indication of enhanced antioxidant activity. No significant changes in proline content perhaps implied that antioxidant activity may not have been proline-mediated, or affected by changes in proline concentration (Choudhary et al., 2007). The results obtained from this study were inconsistent with the findings Singh et al. (2012) and Krishnaveni et al. (2015).

\section{CONCLUSION}

The findings of this study showed that iron concentrations greater than $300 \mathrm{mg} \mathrm{kg}^{-1}$, have a negative impact on biochemical processes associated iron metabolism in cowpea. These findings have assisted in understanding the mechanisms, by which there is high yield loss in cowpea due to iron toxicity. The documentation of these observable physiological and biochemical changes will serve as background for further studies into the selection of iron-tolerant cultivars to improve the cultivation and production of cowpea in regions associated with ferruginous soils.

\section{ACKNOWLEDGEMENT}

The authors are grateful to the Genetic Recourses Centre of the International Institute for Tropical Agri- culture (GRC, IITA), Ibadan, headed by Prof. Michael Abberton, for graciously providing all the accessions used for the study and also to Professor Anoliefo, G.O. for providing the Environmental Biotechnology and Sustainability Research (EBSR) laboratory where most of the work was carried out. All EBSR members are appreciated for their contributions to the success of this research work.

\section{CONFLICT OF INTEREST}

There is no conflict of interest as it concerns this research study.

\section{REFERENCES}

Abdel-Haleem, A. H. E. (2015). Seed germination percentage and early seedling establishment of five (Vigna unguiculata L. (Walp) genotypes under salt stress. European Journal of Experimental Biology, 5(2), 22-32.

Ahenkora, K., AduDapaah, H. K., \& Agyemang, A. (1998). Selected nutritional components and sensory attributes of cowpea ( $V$. unguiculata (L.) Walp.) leaves. Plant Foods Human Nutrition, 52, 221-229. https://doi. org/10.1023/A:1008019113245

Ahmad, M. J., Akhtar, Z. A., \& Zahir J. A. (2012). Effect of cadmium on seed germination and seedling growth of four wheat (Triticum aestivum L.) cultivars. Pakistan Journal of Botany, 44(5), 1569-1574.

Araújo, A.S. Ferreira de, L., Luciano, M., Melo, W., José de, S. Vilma, M., \& Araujo, F. F. (2016). Soil properties and cowpea yield after six years of consecutive amendment of composted tannery sludge. Acta Scientiarum Agronomy, 38(3), 407-413. https://doi.org/10.4025/actasciagron.v38i3.28281 
Arleta, M., Aneta, P., Anna, M., Anetta, H., Danuta, B., \& Barbara, T. (2012). Antioxidative defense system in Pisum sativum roots exposed to heavy metals $(\mathrm{Pb}, \mathrm{Cu}, \mathrm{Cd}, \mathrm{Zn})$. Polish Journal of Environmental Studies, 21(6), 1721-1730.

Arnon, D.I. (1949). Copper enzymes in isolated chloroplast Polyphenol Oxidase in Beta vulgaris. Plant Physiology, 24, 1-15. https://doi.org/10.1104/pp.24.1.1

Bates, L., Waldren, R.P., \& Teare, I.D. (1973). Rapid determination of free proline for water-stress studies. Plant and Soil, 39, 205-207. https://doi.org/10.1007/BF00018060

Batty, L.C., \&Younger, P.L. (2003). Effects of External Iron Concentration upon Seedling Growth and Uptake of Fe and Phosphate by the Common Reed (Phragmites australis (Cav.) Trin ex.Steudel). Annals of Botany, 92, 801-806. https://doi.org/10.1093/aob/mcg205

Beauchamp, C., \& Fridovich, I. (1971). Superoxide dismutase: Improved assays and an assay applicable to acrylamide gels. Analytical Biochemistry, 44, 276-287. https://doi. org/10.1016/0003-2697(71)90370-8

Bhagyashree, K.,Satyendra, N., \& Prasad, S.M. (2016). Effect of cadmium doses on seed germination and morphology parameters of wheat (Triticum aestivum L.). The Ecoscan, 10(3\&4), 491-494.

Bhattacharjee, S. (2008). Triadimefon pretreatment protects newly assembled membrane system and causes up-regulation of stress proteins in salinity stressed Amaranthus lividus L. during early germination. Journal of Environmental Biology, 29, 805-810.

Choudhary, M., Jetley, U.K., Khan, M.A, Zutshi, S., \& Fatma, T. (2007). Effect of heavy metal stress on proline, malondialdehyde, and superoxide dismutase activity in the cyanobacterium Spirulina platensis-S5. Ecotoxicology and Environmental Safety, 66, 204-209. https://doi.org/10.1016/j. ecoenv.2006.02.002

Clinfton, P.M. (2011). Protein and coronary heart disease: the role of different protein sources. Current Atherosclerosis Report, 13(6), 493-498. https://doi.org/10.1007/s11883-0110208-x

Dufey, I., Hie, M.P., Hakizimana, P., Draye, X., Lutts, S., Kone, B., Drame, K.N., Konate, K.A., Sie, M., \& Bertin, P. (2012). Multienvironment QTL mapping and consistency across environments of resistance mechanisms to ferrous iron toxicity in rice. Crop Science, 52, 539-550. https://doi. org/10.2135/cropsci2009.09.0544

Erja, T., Eava-Kaisa, H., Kari, T., \& Kari, L. (2001). Comparison of two methods used to analyse lipid peroxidation from Vaccinium myrtillus (L.) during snow removal, reacclimation and cold acclimation Journal of Experimental Botany, 52(365), 2375-2380. https://doi.org/10.1093/ jexbot $/ 52.365 .2375$

Esma, H. A., \& Gulnur, A. (2016). Determination of SOD, POD, PPO and CAT Enzyme Activities in Rumex obtusifolius L. Annual Research \& Review in Biology, 11(3), 1-7. https:// doi.org/10.9734/ARRB/2016/29809

Ezhilvannan, D., Sharavanan, P.S., \& Vijayaragavan, M. (2011). Changes in growth, sugar and starch contents in groundnut (Arachis hypogaea L.) plants under nickel toxicity. Current Botany, 2(8), 24-26.

Gao, Y., Mao, L., \& Zhou P. (2010). Antioxidative defense sys- tem differences among four plants under combined $\mathrm{Pb}$ and Cd stress. Chinese Journal of Eco-Agriculture, 18(4), 836842. https://doi.org/10.3724/SP.J.1011.2010.00836

Health, R.L., \& Packer, L. (1968). Photoperoxidation in an isolated chloroplast I. Kinetics and stoichiometry of fatty acid peroxidation. Archives in Biochemistry and Biophysics, 125, 189-198. https://doi.org/10.1016/0003-9861(68)90654-1

IKhajiagbe, B., \& Mgbeze, G.C. (2010).Growth and yield responses of Sphenostylis stenocarpa (Hochst ex. A Rich) Harms (African yam bean) to potassium application. African Journal of Biotechnology, 9(25), 3769-3774.

Ikhile, C.I. (2016). Geomorphology and Hydrology of the Benin Region, Edo State, Nigeria. International Journal of Geosciences, 7, 144-157. https://doi.org/10.4236/ijg.2016.72012

Imasuen, O.I., \& Onyeobi, T.U.S. (2013). Chemical compositions of soils in parts of Edo State, Southwest Nigeria and their relationship to soil productivity. Journal of Applied Sciences and Environmental Management, 17(3), 379-386. https://doi.org/10.4314/jasem.v17i3.6

Krishnaveni, M., Kumar, J. S., \& Sharvanan, P.S. (2015). Influence of lead on biochemicals and proline contents of $\mathrm{Vi}$ gna unguiculata (L.) Walp. International Journal of Plant Science, 10(2), 142-151. https://doi.org/10.15740/HAS/ IJPS/10.2/142-151

Luck, H. (1974). Methods in enzymatic analysis. New York, NY: Academic Press.

Malar, S., Shivendra ,V. S., Favas, J.C.P., \& Perumal, V. (2016). Lead heavy metal toxicity induced changes on growth and antioxidative enzymes level in water hyacinths (Eichhornia crassipes (Mart.)). Botanical Studies, 55, 54. https://doi. org/10.1186/s40529-014-0054-6

Marin, A., Santos, D.M.M., Banzatto, D.A., \& Codognotto, L.M. (2006). Influência da disponibilidade hídrica e acidez do solo nos teores de prolina livre de guandu. Pesquisa Agropecuária Brasileira, 41, 355-358. https://doi.org/10.1590/ S0100-204X2006000200023

Maxwell, K., \& Johnson, G.N. (2000). Chlorophyll fluorescence - A practical guide. Journal of Experimental Botany, 51, 659668. https://doi.org/10.1093/jexbot/51.345.659

Mitra, G. N., Sahu, S. K., \& Nayak, R. K. (2009). Ameliorating effects of potassium on iron toxicity in soils of Orissa. Presentation at the IPI-OUAT-IPNI International Symposium, 5-7 November 2009, OUAT, Bhubaneswar, Orissa, India.

Nabil, M., \& Coudret, A. (1995). Effects of sodium chloride on growth, tissue elasticity and solute adjustment in two Acacia nilotica subspecies. Physiologia Plantarum, 93(2), 217 224. https://doi.org/10.1111/j.1399-3054.1995.tb02220.x

Nelson, N. (1944). A photometric adaptation of the Somogyis method for the determination of reducing sugar. Analytical Chemistry, 3, 426-428.

Olasoji, J.O., Olosunde, A.A., \& Okoh, J. O. (2013). Physiological Quality of Cowpea Seeds Produced in Southwestern Nigeria. Greener Journal of Agricultural Sciences, 3(6), 469473. https://doi.org/10.15580/GJAS.2013.3.10031279

Onyango, D.A., Fredrickson, E., Mathew, M. D., Abdelbagi, M. I., \& Khady, N. D. (2019) Mechanistic understanding of iron toxicity tolerance in contrasting rice varieties from Africa: 1. Morpho-physiological and biochemical re- 
sponses. Functional Plant Biology, 46, 93-105. https://doi org/10.1071/FP18129

Prasad, A.G.D., Rahimpouran, S., \& Komala H. P. (2014). Ecotoxicological effects of iron on the activities of antioxidant enzymes in Safflower (Carthamus tinctorius L.) seedlings. International Journal of Pure and Applied Bioscience, 2(5), 118-123

Priti, B., Ashish, K.C., \& Prasad, P. (2009). Effect of Enhanced Lead and Cadmium in soil on Physiological and Biochemical attributes of Phaseolus vulgaris L. Nature and Science, 7(8), 63-75.

Ratering, S., \& Schnell, S. (2000). Localization of iron-reducing activity in paddy soil by profile studies. Biochemistry, 48, 341-365. https://doi.org/10.1023/A:1006252315427

Sadeghi, H., Khazaei, F., Yari, L., \& Sheidaei, S. (2011). Effect of seed osmo-priming on seed germination behavior and vigor of soybean (Glycine max L.). ARPN Journal Agricultural and Biological Science, 6, 39-42.

Sadeghipour, H., Abdolzadeh, A., \& Mehrabanjoubani, P. (2008). Iron Toxicity in Rice (Oryza sativa L.), under Different Potassium Nutrition. Asian Journal of Plant Sciences, https://doi.org/10.3923/ajps.2008.251.259

Sankar, G. K., \& Selvaraju, M. (2015). Growth and boichemical contents of Cowpea (Vigna unguiculata L.) on the application of zinc. World Scientific News, 16, 73-83.
Singh, G., Agnihotri, R., Reshma, R.S., \& Ahmad, M. (2012). Effect of lead and nickel toxicity on chlorophyll and proline content of Urd (Vigna mungo L.) seedlings. International Journal of Plant Physiology and Biochemistry, 4, 136-141. https://doi.org/10.5897/IJPPB12.005

Spence, J.D., Jenkins, D.J., \& Davignon, J. (2010). Dietary cholesterol and egg yolks: not for patients at risk of vascular disease. Canadian Journal of Cardiology, 26, e336-9. https:// doi.org/10.1016/S0828-282X(10)70456-6

Sun, C., Ma, L., \& Sheng, L. (2009).Soil naphthaline pollution stress on corn (Zea mays L.) seedling physiological effect. Journal of Agro-Environment Science, 28(3), 443-448.

Suresh, S. (2005). Characteristics of soils prone to iron toxicity and management - a review. Agricultural Reviews, 26(1), $50-58$.

Wada, B.Y., \& Abubakar, B.Y. (2013). Germination studies in some varieties of Vigna unguiculata L.Walp. (Cowpea) from Northern Nigeria. Parkistan Journal of Biological Sciences, 16(20), 1220-1222. https://doi.org/10.3923/ pjbs.2013.1220.1222

Yamauchi, M., \& Peng, X. X. (1993). Ethylene production in rice bronzing leaves induced by ferrous iron. Plant Soil, 149 , 227-234. https://doi.org/10.1007/BF00016613 